\title{
PENGARUH KOMPENSASI TERHADAP KINERJA KARYAWAN HOME INDUSTRI CAHAYA ROTI DI KURUNGANNYAWA GEDONG TATAAN PESAWARAN LAMPUNG
}

\author{
Khairul Saleh ${ }^{(1)}$, Nelson ${ }^{(2)}$, Budi Arisandi ${ }^{(3)}$ \\ Fakultas Ekonomi Universitas Sang Bumi Ruwa Jurai \\ khairul.saleh@fe.saburai.ac.id,nelson@fe.saburai.ac.id,arisandi_budi17@gmail.com
}

\begin{abstract}
Abstrak. Kompensasi adalah segala sesuatu yang diterima oleh pegawai sebagai balas jasa atas kerja mereka. Ada Pengaruh Kompensasi Terhadap Kinerja Karyawan Home Industri Cahaya Rotidi Kurungannyawa Gedongtataan Pesawaran Lampung. Penelitian ini bertujuan untuk mengetahui pengaruh kompensasi terhadap kinerja karyawan yang bekerja di Toko Cahaya Roti Kurungannyawa Pesawaran. Jenis Penelitian ini adalah studi kasus. Jumlah responden dalam penelitian ini sebanyak 25 orang. Teknik pengambilan sampel menggunakan teknik Sampling Jenuh. Teknik analisis data dilakukan dengan menggunakan regresi linier sederhana. Berdasarkan hasil analisis regresi linier sederhana disimpulkan bahwa kompensasi berpengaruh terhadap kinerja. Hal ini dibuktikan dari hasil uji hipotesis (Uji t) yaitu 2,351 > 2,069 maka $\mathrm{H}_{0}$ ditolak dan $\mathrm{H}_{\mathrm{a}}$ diterima. Dari hasil penelitian ini, diperoleh bahwa ada pengaruh kompensasi terhadap kinerja karyawan yang bekerja di Toko Cahaya Roti Kurungannyawa Pesawaran.
\end{abstract}

Kata kunci: Karyawan, Kinerja, Kompensasi, Pengaruh.

\section{PENDAHULUAN}

Manusia adalah salah satu sumber daya yang bisa dikatakan cukup penting dan memiliki kemampuan untuk terus berkembang dan perlu mendapatkan perhatian dari pihak perusahaan. Perhatian ini diperlukan untuk mengingat dalam menjalankan aktivitasnya, perusahaan akan selalu berhadapan dengan sumber daya manusia yang dimilikinya. Dengan demikian pembinaan terhadap sumber daya manusia perlu terus mendapatkan perhatian mengingat pesan sumber daya manusia yang besar dalam suatu perusahaan.

Manusia selalu berperan aktif dan dominan dalam setiap organisasi. Sebaikbaiknya program yang dibuat oleh perusahaan akan sulit untuk dapat dijalankan tanpa peran aktif karyawan yang dimiliki perusahaan tersebut. Dari pernyataan tersebut dapat diketahui arti penting karyawan dalam suatu perusahaan.
Karena perhatian organisasi atau perusahaan terhadap pemberian kompensasi secara rasional dan adil maka dari itu pemberian kompensasi dapat meningkatkan kinerja karyawan. Jika pemberian kompensasi yang diberikan kepada karyawan tidak seimbang maka prestasi kerja maupun kepuasan kerja karyawan akan menurun.

Kompensasi adalah segala sesuatu yang diterima oleh pegawai sebagai balas jasa atas kerja mereka, pada dasarnya kompensasi merupakan kontribusi yang diterima oleh pegawai atas pekerjaan yang telah dikerjakannya. Program kompensasi adalah bagian penting bagi organisasi atau perusahaan karena mencerminkan upaya organisasi atau perusahaan untuk mempertahankan sumber daya manusia sebagai komponen utama, dan merupakan biaya yang paling penting. Kompensasi juga merupakan salah satu aspek yang berarti bagi pegawai, karena bagi individu 
atau pegawai besarnya kompensasi mencerminkan ukuran nilai karya mereka diantara para pegawai itu sendiri.

Kompensasi itu sendiri dibagi menjadi dua yaitu kompensasi langsung (financial) dan tak langsung (non financial), kompensasi langsung merupakan imbalan jasa kepada pegawai yang diterima secara langsung, rutin atau periodik karena yang bersangkutan telah memberikan bantuan atau sumbangan untuk mencapai tujuan organisasi, dan kompensasi langsung meliputi gaji, bonus/insentif, komisi. Selain kompensasi langsung, kompensasi tak langsung juga mempunyai peranan yang tak kalah pentingnya untuk meningkatkan kinerja karyawan. Dan kompensasi tak langsung meliputi tunjangan hari raya dan tunjangan kesehatan.

Setiap kegiatan atau usaha yang dilakukan manusia dalam suatu perusahaan tidak terlepas dari motif pribadi untuk memenuhi kebutuhannya. Melalui kerja manusia berharap dapat memperoleh imbalan atau kompensasi yang akan digunakan untuk memenuhi kebutuhannya tersebut. Kebutuhan manusia bermacammacam dan berbeda-beda antara yang satu dengan yang lainnya. Kinerja merupakan perwujudan kerja yang dilakukan oleh karyawan yang biasanya dipakai sebagai dasar penilaian terhadap karyawan atau organisasi, sehingga perlu diupayakan untuk meningkatkan kinerja.

Pada Home Industri Cahaya Roti, kompensasi diberitahukan home industri kepada karyawan pada saat pemberian kontrak kerja karyawan, isi dari kontrak kerja tersebut berupa pemberian gaji job description, dan aturan-aturan lain seperti sanksi atas pelanggaran dan lain-lain sehingga karyawan mengetahui terlebih dahulu besar kompensasi dan besarnya tanggung jawab karyawan. Jika kompensasi yang diberikan sesuai, maka karyawan akan berusaha memberikan kinerja yang baik tetapi jika kompensasi dirasa tidak sesuai dengan yang diharapkan, maka karyawan akan cenderung tidak memberikan kinerja yang diharapkan. Kompensasi yang diberikan dapat dilakukan dengan cara harian, mingguan atau bulanan.

Berdasarkan uraian tersebut peneliti tertarik melakukan penelitian dengan judul:

"Pengaruh Kompensasi Terhadap Kinerja Karyawan Home Industri Cahaya Roti di Kurungannyawa Gedongtataan Pesawaran Lampung”.

\section{KAJIAN TEORI}

\section{Definisi Kompensasi}

Dalam hubungannya dengan peningkatan kesejahteraan hidup para pegawai, suatu organisasi harus secara efektif memberikan kompensasi sesuai dengan beban kerja yang diterima pegawai. Kompensasi merupakan salah satu faktor baik secara langsung atau tidak langsung mempengaruhi tinggi rendahnya kinerja pegawai. Karena itu semestinya pemberian kompensasi kepada pegawai perlu mendapat perhatian khusus dari pihak manajemen instansi agar motivasi para pegawai dapat dipertahankan dan kinerja pegawai diharapkan dapat meningkat.

Salah satu fenomena yang muncul dewasa ini adalah adanya kebijakan pemberian kompensasi yang cenderung masih belum sepenuhnya sesuai dengan harapan pegawai sedangkan kompensasi itu sendiri ialah merupakan salah satu faktor untuk mendorong pegawai agar memiliki kinerja yang lebih tinggi. Bagi perusahaan, kompensasi memiliki arti penting karena kompensasi mencerminkan upaya organisasi dalam mempertahankan dan meningkatkan kesejahteraan karyawannya. Pengalaman menunjukan bahwa kompensasi yang tidak memadai dapat menurunkan prestasi kerja, motivasi kerja, dan kepuasan kerja karyawan, bahkan dapat 
menyebabkan karyawan yang potensial keluar dari perusahaan.

Kompensasi ditinjau dari sudut pandang perusahaan merupakan unsur biaya yang dapat mempengaruhi posisi persaingan perusahaan, proses rekrutmen, dan tingkat perputaran karyawan. Sedangkan ditinjau dari sudut pandang karyawan merupakan unsur pendapatan yang mempengaruhi gaya hidup, status, harga diri, dan perasaan karyawan terhadap perusahaan untuk tetap bersama perusahaan atau mencari pekerjaan lainnya. Selain itu juga merupakan alat manajemen bagi perusahaan untuk meningkatkan motivasi kerja, meningkatkan produktivitas, dan mempengaruhi kepuasan kerja.

Menurut Ardana (2012) Kompensasi adalah segala sesuatu yang diterima oleh karyawan sebagai balas jasa atas kontribusinya kepada perusahaan atau organisasi. Menurut Hasibuan (2013) Kompensasi adalah semua pendapatan yang berbentuk uang, barang langsung ataupun tidak langsung yang diterima oleh karyawan sebagai imbalan atas yang diberikan kepada perusahaan. Menurut Sastrohadiwiryo dalam bukunya Yuniarsih (2011) Kompensasi adalah imbalan jasa atau balas jasa yang diberikan oleh perusahaan kepada para tenaga kerja, karena para tenaga kerja tersebut telah memberikan sumbangan tenaga dan pikiran demi kemajuan perusahaan guna mencapai tujuan yang ditetapkan.

Berdasarkan definisi para pakar tersebut penulis menyimpulkan bahwa kompensasi merupakan unsur biaya pengeluaran bagi perusahaan yang dikeluarkan sebagai balas jasa kepada karyawan atas pengorbanan sumber daya (waktu, tenaga, dan pikiran) serta kompetensi (pengetahuan, keahlian, dan kemampuan) yang telah mereka curahkan selama periode waktu tertentu sebagai sumbangan pada pencapaian tujuan organisai dan diterimakan karyawan sebagai pendapatan yang merupakan bagian dari hubungan kepegawaian yang dikemas dalam suatu sistem imbalan jasa.

\section{Tujuan kompensasi}

Menurut S. P Hasibuan (2013) adalah sebagai berikut:

1. Ikatan kerja sama, dengan pemberian kompensasi terjalinlah ikatan kerjasama formal antara atasan dengan karyawan. Karyawan harus mengerjakan tugasnya dengan baik, sedangkan pengusaha atau atasan wajib membayar kompensasi sesuai dengan perjanjian yang teah disepakati.

2. Kepuasan kerja, dengan balas jasa karyawan akan dapat memenuhi kebutuhan fisik, status sosial, dan egoistiknya sehingga memperoleh kepuasan kerja dari jabatannya.

3. Pengadaan efektif, jika program kompensasi ditetapkan cukup besar, pengadaan karyawan yang qualifield untuk perusahaan akan lebih mudah.

4. Motivasi, jika balas jasa yang diberikan cukup besar, manajer akan lebih mudah memotivasi bawahannya.

5. Stabilitas karyawan, dengan program kompensasi atas prinsip adil dan layak serta eksternal konsistensi yang kompetitif maka stabilitas karyawan akan lebih terjamin karena turnover relatif kecil.

6. Disiplin, dengan pemberian balas jasa yang cukup besar maka disiplin karyawan semakin membaik, mereka akan menyadari serta menaati peraturan peraturan yang berlaku.

7. Pengaruh serikat buruh, dengan program kompensasi yang baik pengaruh serikat 
buruh dapat dihindarkan dan karyawan akan berkonstentrasi pada pekerjaannya.

8. Pengaruh pemerintah, jika program kompensasi sesuai dengan undangundang perburuhan yang berlaku (seperti batas upah minimum) maka intervensi pemerintahan dapat dihindarkan.

\section{Pengertian Kinerja}

Kinerja berasal dari kata job performance atau actual performance yang berarti prestasi kerja atau prestasi sesungguhnya yang dicapai oleh seseorang. Pengertian kinerja (prestasi kerja) adalah hasil kerja secara kualitas dan kuantitas yang dicapai oleh seorang pegawai dalam melaksanakan fungsinya sesuai dengan tanggung jawab yang diberikan kepadanya.

Performance atau kinerja merupakan hasil atau keluaran dari suatu proses (Nurlaila, 2010). Menurut pendekatan perilaku dalam manajemen, kinerja adalah kuantitas atau kualitas sesuatu yang dihasilkan atau jasa yang diberikan oleh seseorang yang melakukan pekerjaan (Luthans, 2005). Kinerja adalah hasil kerja baik secara kualitas maupun kuantitas yang dicapai oleh seseorang dalam melaksanakan tugas sesuai tanggung jawab yang diberikan (Mangkunagara, 2002).

Kinerja adalah hasil atau tingkat keberhasilan seseorang secara keseluruhan selama periode tertentu dalam melaksanakan tugas dibandingkan dengan berbagai kemungkinan, seperti standar hasil kerja, target atau sasaran atau kriteria yang telah ditentukan terlebih dahulu telah disepakati bersama (Rivai dan Basri, 2005).

\section{Faktor-Faktor Yang Mempengaruhi Kinerja}

Faktor kemampuan (ability) Secara psikologis, kemampuan terdiri dari kemampuan potensi (IQ) dan kemampuan reality (knowledge + skill). Artinya, pemimpin dan karyawan yang memiliki IQ diatas rata rata (IQ 110-120) apalagi IQ superior, very superior, gifted dan genius dengan pendidikan yang memadai untuk jabatannya dan terampil dalam mengerjakan pekerjaan sehari hari, maka akan lebih mudah mencapai kinerja maksimal.

Faktor motivasi (motivation) Motivasi diartikan suatu sikap (attitude) pimpinan dan karyawan terhadap situasi kerja (situation) di lingkungan organisasinya. Mereka yang bersikap positif terhadap situasi kerjanya akan menunjukan motivasi kerja yang tinggi dan sebaliknya jika mereka bersikap negatif terhadap situasi kerjanya maka akan menunjukan motivasi kerja yang rendah. Situasi kerja yang dimaksud mencakup antara lain hubungan kerja, fasilitas kerja, iklim kerja, kebijakan pemimpin, pola kepemimpinan dan kondisi kerja.

\section{METODE PENELITIAN}

\section{Objek Penelitian}

Objek penelitian ini adalah karyawan yang bekerja di Home Industri Cahaya Roti di Kurungannyawa Gedongtataan Pesawaran Lampung. Penelitian dilaksanakan di kabupaten Pesawaran, Lampung. Penelitian ini dilaksanakan pada Mei sampai dengan Juli 2019.

\section{Metode dan Teknik Pengumpulan Data}

Dalam penelitian ini jenis data yang diperlakukan adalah :

\section{a. Data Primer}

Data primer merupakan data dasar yang akan diperoleh langsung tanpa perantara orang atau lembaga lain sebagai pihak ketiga. Data primer ini diperoleh dengan wawancara melalui responden dengan menggunakan daftar pertanyaan. 
b. Data Sekunder

Data skunder merupakan data yang diperoleh melalui orang lain yang berhubungan dengan permasalahan yang dipecahkan. Data sekunder ini diperoleh melalui cara studi dokumenter yaitu mengumpulkan dan mempelajari brosurbrosur serta dokumen organisasi.

Adapun teknik yang digunakan dalam pengumpulan data adalah dengan :

1. Observasi, yaitu mengadakan survey atau pengamatan langsung kelokasi penelitian.

2. Interview atau wawancara, yaitu mengadakan tanya jawab langsung dengan pegawai.

3. Dokumentasi, yaitu mengumpulkan dan mencatat dokumentasi yang relevan.

4. Kuisioner, yaitu membuat pertanyaan yang berhubungan dengan varibael penelitian.

\section{Sampel dan Populasi}

Menurut Sugiyono (2014) populasi adalah wilayah generalisasi obyek/subyek yang mempunyai kualitas dan karakteristik tertentu yang diterapkan oleh peneliti untuk diperlajari dan kemudian ditarik kesimpulannya dan sampel adalah bagian dari jumlah dan karakteristik yang dimiliki oleh populasi tersebut. Dalam penelitian ini populasi dan sampel yang akan diteliti adalah Karyawan yang bekerja di Home Industri Cahaya Roti di Kurungannyawa Gedongtataan yang berjumlah 25 karyawan.

\section{Metode Analisis Data}

Menurut Sugiyono (2016), metode penelitian kuantitatif adalah suatu metode penelitian yang mengkombinasikan atau menggabungkan antara metode kuantitatif dan metode kualitatif untuk digunakan secara bersema-sama dalam suatu kegiatan penelitian, sehingga diperoleh data yang lebih komperhensif, valid, reliabel, dan objektif.

Penelitian ini menggunakan dua jenis metode penelitian (mixed method), yaitu studi kasus dan metode kuantitatif, studi kasus merupakan pendekatan penelitian yang berfokus dan memperhatikan dengan seksama pada suatu kasus dengan intensif dan rinci, dengan penggalian informasi dan analisa secara mendalam.

Persamaan Regresi Linear Sederhana menentukan persamaan regresi linear sederhana untuk X :

$$
Y=a+b X+e
$$

Keterangan:

$$
\begin{aligned}
\mathrm{Y} & =\text { Kinerja karyawan } \\
\mathrm{a} & =\text { Konstanta } \\
\mathrm{b} & =\text { Koefisien regresi } \mathrm{X} \\
\mathrm{X} & =\text { Kompensasi } \\
\mathrm{e} & =\text { Faktor kesalahan }
\end{aligned}
$$

Untuk mengetahui besarnya pengaruh, penghitungan koefisien korelasi tersebut kemudian dilanjutkan dengan Rumus Koefisien Determinasi atau Koefisien Penentu (KP):

$$
K P=(r)^{2} x 100 \%
$$

Untuk menguji secara hipotesis secara parsial digunakan Uji t dengan rumus :

$$
t_{\text {hitung }}=\frac{r \sqrt{N-2}}{\sqrt{1-r^{2}}}
$$

Keterangan:

$$
\begin{array}{ll}
\mathrm{t}_{\text {hitung }} & =\text { Nilai } \mathrm{t} \\
\mathrm{r} & =\text { Koefisien Korelasi } \\
\mathrm{N} & =\text { Jumlah responden }
\end{array}
$$

Kriteria untuk Uji $\mathrm{t}$ adalah sebagai berikut :

a) Jika $t_{\text {hitung }}>t_{\text {tabel }}$ maka Ha diterima dan Ho ditolak. 
b) Jika $t_{\text {hitung }} \leq \mathrm{t}_{\text {tabel }}$ maka Ha ditolak dan Ho diterima.

\section{HASIL DAN PEMBAHASAN}

\section{Uji Validitas dan Reliabilitas}

Uji validitas dilakukan untuk mengukur valid tidaknya suatu instrumen. Uji validitas dilakukan dengan menggunakan teknik korelasi Pearson Moment. Dalam uji validitas, kriteria suatu nilai dinyatakan valid apabila hasil uji $\mathrm{r}_{\text {hitung }}$ $>r_{\text {tabel. }}$ Dalam penelitian ini, uji validitas dilakukan menggunakan 25 kuesioner yang dibagikan langsung kepada responden.

Diketahui $\mathrm{N}=25$ dan $\alpha=5 \%$, maka $\mathrm{r}_{\text {tabel }}=0,3961$. Setiap item peryataan dapat dikatakan valid jika $r_{\text {hitung }}>0,3961$. Berikut adalah hasil uji validitas yang penulis dapatkan, yaitu Perusahaan memperhatikan pemenuhan kebutuhan dan fasilitas karyawan yang memadai. Yang terendah yaitu item pernyataan nomor 2 yaitu bonus yang diberikan perusahaan sesuai dengan waktu kerja lembur dengan rata-rata 3,44 .

Berdasarkan data diperoleh bahwa semua variabel bersifat reliabel dan instrumen yang terdapat pada penelitian ini sudah dapat dipercaya sebagai alat pengumpulan data dan mampu mengungkap informasi yang sebenarnya, hal ini ditunjukan dengan nilai semua Cronbach Alpha variabel >0,60.

\section{Analisis Kuantitatif}

Analisis regresi linier sederhana bertujuan untuk mengetahui bagaimana pengaruh variabel independen terhadap variabel dependen. Untuk mengetahui kuat lemahnya pengaruh dari Kompensasi terhadap Kinerja dilihat dari koefisien regresi ( $\beta$ ). Adapun hasil analisis regresi linier sederhana adalah $\mathrm{Y}=14.994+0,255$ $\mathrm{X}$. Nilai $\mathrm{t}$ hitung yang diperoleh dengan tingkat kepercayaan 95\%, maka nilai a $=$ 0,05 . Rumus t tabel adalah $0,05 / 2=0,025$ (uji dua sisi), derajat bebas (df) $=n-k$ atau $25-2=23$ diperoleh nilai $\mathrm{t}$ tabel sebesar 2.069 .

Berdasarkan jenis kelamin responden yang diperoleh penulis mayoritas adalah laki-laki dengan proporsi $52 \%$ responden laki-laki dan $48 \%$ responden perempuan. Berdasarkan usia, responden yang diperoleh penulis mayoritas adalah usia dari 30-39 dengan proporsi $40 \%$ dan yang terkecil adalah usia dari 40-49 dengan frekuensi $4 \%$.

Mayoritas pekerja atau karyawan yang bekerja di Toko Cahaya Roti Kurungannyawa Pesawaran adalah berjenis kelamin laki-laki dengan range usia dari usia 30-39 tahun. Hasil analisis deskriptif IV.3 secara umum menunjukkan keseluruhan rata-rata variabel kompensasi yaitu 3,86. Angka ini menunjukkan bahwa kompensasi termasuk dalam kategori tinggi ( $\mathrm{T}$ ) karena skor rata-rata masih berada pada rentang 3,40-4,19 yang artinya kompensasi yang diberikan oleh Toko Cahaya Roti Kurungannyawa Pesawaran ini termasuk dalam kompensasi yang sesuai atau bisa dikatakan layak.

Hasil analisis deskriptif secara umum menunjukkan keseluruhan rata-rata variabel kinerja yaitu 3,98 yang termasuk dalam kategori tinggi ( $T$ ) yang berarti bahwa karyawan yang bekerja di Toko Cahaya Roti Kurungannyawa Pesawaran ini mampu bekerja dengan baik.

Berdasarkan hasil analisis regresi linier sederhana disimpulkan bahwa kompensasi berpengaruh terhadap kinerja. Hal ini dibuktikan dari hasil uji hipotesis (Uji t) yaitu 2,351 > 2,069 maka $\mathrm{H}_{0}$ ditolak dan $\mathrm{H}_{\mathrm{a}}$ diterima. Pengaruh kompensasi ini bersifat positif dengan nilai signifikansi (Sig) 0,020 lebih kecil dari $1 / 2$ a $5 \%(0,020<0,025)$ artinya apabila pemberian kompensasi perusahaan menurut persepsi karyawan semakin baik, maka hal tersebut akan 
semakin mendorong kinerja karyawan yang bekerja di perusahaan tersebut menjadi lebih baik karena pemberian kompensasi yang baik.

\section{KESIMPULAN DAN SARAN}

\section{Kesimpulan}

Berdasarkan analisis dan pembahasan maka dapat diambil kesimpulan bahwa hasil perhitungan nilai rata-rata pada variabel Kompensasi (X) yang diberikan Toko Cahaya Roti Kurungannyawa Pesawaran dengan nilai 3,86, termasuk dalam kategori tinggi. Hasil perhitungan nilai rata-rata pada variabel Kinerja (Y) dari karyawan yang bekerja di Toko Cahaya Roti Kurungannyawa Pesawaran dengan nilai 3,98, termasuk dalam kategori tinggi. Dari uraian di atas, berarti Kompensasi berpengaruh terhadap kinerja karyawan di Toko Cahaya Roti Kurungannyawa Pesawaran.

\section{Saran}

Berdasarkan kesimpulan hasil analisis dan kesimpulan yang telah diuraikan, maka saran yang dapat penulis berikan untuk dapat dijadikan pertimbangan adalah sebagai berikut :

1. Pihak perusahaan sebaiknya lebih memperhatikan pemberian bonus kerja yang diberikan kepada karyawan yang bekerja di Toko Cahaya Roti Kurungannyawa Pesawaran ini, agar kinerja karyawan yang bekerja di Toko Cahaya Roti Kurungannyawa Pesawaran ini lebih baik yang sesuai dengan apa yang diharapkan perusahaan.

2. Pihak perusahaan juga harus lebih memperhitungkan ulang waktu yang dibutuhkan untuk proses produksi, sehingga sebagai dasar penilaian kerja karyawan yang lebih adil. Berdasarkan hasil perhitungan nilai rata-rata pada variabel kinerja dan lebih tepatnya pada indikator ketepatan waktu yang memiliki nilai rata-rata terendah dibandingkan indikator-indikator kompensasi lainnya.

\section{DAFTAR PUSTAKA}

Ardana. 2012. Manajemen Sumber Daya Manusia. Yogyakarta: Graha Ilmu.

Handoko. 2002. Manajemen Personalia dan Sumberdaya Manusia. Yogyakarta: BPFE.

Hasibuan, Malayu S.P. 2013. Manajemen Sumber Daya Manusia Edisi Revisi. Jakarta: Bumi Aksara.

Ishak, R. 2017. Pengaruh Kompensasi Terhadap Kinerja Karyawan Pada Meubel Rotan Cahaya Bersatu Kota Gorontalo. Jurnal SDM.

Maheswari, H., Lutvy, L. R. 2015. Pengaruh Kompensasi Dan Motivasi Terhadap Kinerja Karyawan Pt Bank Ekonomi Raharja Tbk Area Jakarta 5. Jurnal Manajemen. Vol.19, No.02. Pp 230248.

Mangkunegara, A. P. (2002), Manajemen Sumber Daya Manusia. Bandung: PT. Remaja Rosda Karya.

Nathania, Catherine. 2016. Pengaruh Kompensasi Terhadap Kinerja Karyawan Pada Pd Damai Motor Bandar Lampung. Universitas Lampung. Bandar Lampung.

Nurlaila. 2010. Manajemen Sumber Daya Manusia I. Ternate: Penerbit LepKhair. 
Simamora, H. 2004. Manajemen Sumber

Daya Manusia. Edisi Ke-3.

Yogyakarta: STIE YKPN.

Sugiyono. 2014. Metode Penelitian Kuantittif,

Kualitatif dan $R \& D$. Bandung:

Alfabeta.

Veithzal, R. 2004. Manajemen Sumber Daya Manusia Untuk Perusahaan. Edisi Pertama. Jakarta: PT Raja Grafindo Persada.

Wiryo, S.H., Siswanto, B. 2003. Manajemen Tenaga Kerja Indonesia Pendekatan Administrative dan Operasional. Jakarta: Bumi Aksara. 